medRxiv preprint doi: https://doi.org/10.1101/2020.08.23.20180422; this version posted August 25, 2020. The copyright holder for this preprint (which was not certified by peer review) is the author/funder, who has granted medRxiv a license to display the preprint in It is made available under a CC-BY-NC-ND 4.0 International license .

\title{
Predicting deseasonalised serum 25 hydroxy vitamin D concentrations in the D-Health Trial: an analysis using boosted regression trees
}

Mary Waterhouse ${ }^{\mathrm{a}}$, Catherine Baxter ${ }^{\mathrm{a}}$, Briony Duarte Romero ${ }^{\mathrm{a}}$, Donald S. A. McLeod ${ }^{\mathrm{a}, \mathrm{b}}$, Dallas R. English $^{\mathrm{c}}$, Bruce K. Armstrong ${ }^{\mathrm{d}}$, Michael W. Clarke ${ }^{\mathrm{e}}$, Peter R. Ebeling ${ }^{\mathrm{f}}$, Gunter Hartel ${ }^{\mathrm{a}}$, Michael G. Kimlin $^{\mathrm{g}}$, Rachel L. O'Connell ${ }^{\mathrm{h}}$, Hai Pham ${ }^{\mathrm{a}, \mathrm{i}}$, Rachael M. Rodney Harris ${ }^{\mathrm{j}}$, Jolieke C. van der Pols ${ }^{\mathrm{k}}$, Alison J. Venn ${ }^{1}$, Penelope M. Webb ${ }^{\mathrm{a}}$, David C. Whiteman ${ }^{\mathrm{a}}$, Rachel E. Neale ${ }^{\mathrm{a}, \mathrm{i} *}$

${ }^{\text {a }}$ Population Health Department, QIMR Berghofer Medical Research Institute, Brisbane, Australia

${ }^{\mathrm{b}}$ Department of Endocrinology and Diabetes, Royal Brisbane and Women's Hospital, Brisbane, Australia

${ }^{c}$ Melbourne School of Population Health, University of Melbourne, Cancer Epidemiology and Intelligence Division, Cancer Council Victoria, Melbourne Australia

${ }^{\mathrm{d}}$ School of Public Health, University of Sydney, Sydney, Australia

${ }^{\mathrm{e}}$ Metabolomics Australia, Centre for Microscopy, Characterisation and Analysis, The University of Western Australia, Perth, Australia.

${ }^{\mathrm{f}}$ Department of Medicine, School of Clinical Sciences, Monash University, Melbourne, Australia

${ }^{g}$ Queensland University of Technology (QUT), School of Biomedical Sciences, Faculty of Health, Brisbane, Australia

${ }^{\mathrm{h}}$ NHMRC Clinical Trials Centre, University of Sydney, Sydney, Australia

${ }^{i}$ School of Public Health, The University of Queensland, Brisbane, Australia

${ }^{j}$ National Centre for Epidemiology and Population Health, College of Health \& Medicine, The Australian National University, Canberra, Australia

${ }^{\mathrm{k}}$ Queensland University of Technology (QUT), School of Exercise and Nutrition Sciences, Faculty of Health, Brisbane, Australia

${ }^{1}$ Menzies Institute for Medical Research, University of Tasmania, Hobart, Australia

Email addresses: Mary.Waterhouse@ qimrberghofer.edu.au; Catherine.Baxter@qimrberghofer.edu.au; Briony.DuarteRomero@ qimrberghofer.edu.au; Donald.McLeod@qimrberghofer.edu.au; d.english@unimelb.edu.au; bruce@ brucekarmstrong.org; michael.clarke@uwa.edu.au; peter.ebeling@monash.edu; Gunter.Hartel@qimrberghofer.edu.au; m.kimlin@qut.edu.au; rachel.oconnell@ctc.usyd.edu.au; Hai.Pham@qimrberghofer.edu.au; Rachael.Rodney@anu.edu.au; j.vanderpols@qut.edu.au; alison.venn@utas.edu.au; Penny.Webb@qimrberghofer.edu.au; David.Whiteman@qimrberghofer.edu.au.

* Corresponding Author: Prof Rachel Neale

QIMR Berghofer Medical Research Institute

Locked Bag 2000, Royal Brisbane Hospital

QLD 4029

Australia

rachel.neale@qimrberghofer.edu.au

$+61-7-3845-3598$ 
medRxiv preprint doi: https://doi.org/10.1101/2020.08.23.20180422; this version posted August 25, 2020. The copyright holder for this preprint (which was not certified by peer review) is the author/funder, who has granted medRxiv a license to display the preprint in It is made available under a CC-BY-NC-ND 4.0 International license .

\begin{abstract}
Background: The D-Health Trial aims to determine whether monthly high-dose vitamin D supplementation can reduce the mortality rate and prevent cancer. We did not have adequate statistical power for subgroup analyses, so could not justify the high cost of collecting blood samples at baseline. To enable future exploratory analyses stratified by baseline vitamin D status, we developed a model to predict baseline serum 25 hydroxy vitamin $\mathrm{D}[25(\mathrm{OH}) \mathrm{D}]$ concentration.
\end{abstract}

Methods: We used data and serum $25(\mathrm{OH}) \mathrm{D}$ concentrations from participants who gave a blood sample during the trial for compliance monitoring and were randomised to placebo. Data were partitioned into training $(80 \%)$ and validation $(20 \%)$ datasets. Deseasonalised serum $25(\mathrm{OH}) \mathrm{D}$ concentrations were dichotomised using cut-points of $50 \mathrm{nmol} / \mathrm{L}, 60 \mathrm{nmol} / \mathrm{L}$ and $75 \mathrm{nmol} / \mathrm{L}$. We fitted boosted regression tree models, based on 13 predictors, and evaluated model performance using the validation data.

Results: The training and validation datasets had $1788(10.5 \%<50 \mathrm{nmol} / \mathrm{L}, 23.1 \%<60 \mathrm{nmol}, 48.8$ $<75 \mathrm{nmol} / \mathrm{L})$ and $447(11.9 \%<50 \mathrm{nmol} / \mathrm{L}, 25.7 \%<60 \mathrm{nmol} / \mathrm{L}$, and $49.2 \%<75 \mathrm{nmol} / \mathrm{L}) \mathrm{samples}$, respectively. Ambient UV radiation and total intake of vitamin D were the strongest predictors of 'low' serum $25(\mathrm{OH}) \mathrm{D}$ concentration. The area under the receiver operating characteristic curves were $0.71,0.70$, and 0.66 for cut-points of $<50 \mathrm{nmol} / \mathrm{L},<60 \mathrm{nmol} / \mathrm{L}$ and $<75 \mathrm{nmol} / \mathrm{L}$ respectively.

Conclusions: We exploited compliance monitoring data to develop models to predict serum $25(\mathrm{OH}) \mathrm{D}$ concentration for D-Health participants at baseline. This approach may prove useful in other trial settings where there is an obstacle to exhaustive data collection.

Keywords: Vitamin D; randomized clinical trial; boosted regression trees; prediction model

\begin{abstract}
Abbreviations
25(OH)D, 25 hydroxy vitamin D; AHS, Australian Health Survey; AUC, area under the ROC curve; BMI, body mass index; BRT, boosted regression tree; CI, confidence interval; IU, international units; MET, metabolic equivalent of task; NPV, negative predictive value; PPV, positive predictive value; QoL, quality of life; RCT, randomised controlled trial; RMSE, root-mean-squared error; ROC, receiver operating characteristic; SD, standard deviation; UV, ultraviolet.
\end{abstract}


medRxiv preprint doi: https://doi.org/10.1101/2020.08.23.20180422; this version posted August 25, 2020. The copyright holder for this preprint (which was not certified by peer review) is the author/funder, who has granted medRxiv a license to display the preprint in

It is made available under a CC-BY-NC-ND 4.0 International license .

\section{INTRODUCTION}

The importance of vitamin D may extend beyond regulating calcium and phosphorus homeostasis. Numerous observational studies have found an inverse association between serum 25 hydroxy vitamin $\mathrm{D}[25(\mathrm{OH}) \mathrm{D}]$ concentration, a marker of vitamin $\mathrm{D}$ status, and risk of many diseases. ${ }^{1}$ Nonetheless, these results may be due to reverse causality or uncontrolled confounding; without high quality randomised trial evidence, we cannot confidently conclude that increasing serum 25(OH)D concentrations in the population through routine vitamin D supplementation or food fortification would improve health.

While randomised controlled trials (RCTs) of non-musculoskeletal outcomes have been performed, ${ }^{2}$ uncertainty of the benefit from supplementing vitamin D persists. A systematic review of metaanalyses and mostly small RCTs found that vitamin D supplementation may prevent premature allcause mortality and mortality from cancer, and possibly reduces the risk of upper respiratory tract infections and asthma exacerbations. ${ }^{2}$ However, there was little evidence of a protective effect for most conditions. ${ }^{2}$ In addition, one large RCT has recently reported no benefit from vitamin D supplementation for incident cancer, cardiovascular disease, or all-cause mortality. ${ }^{3}$ These discrepancies with observational studies may be a consequence of inadequacies in trial designs, such as being under-powered, using a dose that is too low, or being of too short duration, ${ }^{2}$ or may reflect a true lack of benefit from vitamin D supplementation.

We launched the D-Health Trial ${ }^{4}$ in 2014 to determine whether supplementing older people (aged $\geq$ 60 years) with monthly doses of 60,000 international units (IU) of vitamin D over five years can prevent cancer and reduce the mortality rate. Our intention was to replicate what would happen if the Australian population was routinely supplemented with vitamin D, with no prior vitamin D screening. Consequently, we aimed to recruit a representative sample from the older Australian population.

Since our goal was not to determine the benefits of treating vitamin D deficiency, and we do not have statistical power for subgroup analyses by baseline vitamin D status, we could not justify the substantial cost (estimated at several millions of dollars) of measuring $25(\mathrm{OH}) \mathrm{D}$ in all participants at baseline. However, there is value in conducting exploratory analyses stratified by baseline vitamin D status, as any effect of supplementation may be more pronounced amongst people with lower serum $25(\mathrm{OH}) \mathrm{D}$ concentrations prior to supplementation. ${ }^{5}$

During the intervention phase of the D-Health Trial, we collected blood samples from a random sample of participants (approximately 20\%) for the purpose of compliance monitoring. Here we describe how we used measured serum $25(\mathrm{OH}) \mathrm{D}$ concentration from the placebo group (while maintaining blinding), and participants' self-reported data, to develop and validate a model to predict deseasonalised baseline serum 25(OH)D concentrations for the entire cohort. Our approach may be useful to others conducting trials for which prohibitive cost or other obstacles prevent the collection of data on a possible effect modifier.

\section{METHODS}

\section{Trial overview}

The D-Health trial is a double-blind, randomised, placebo-controlled trial of monthly high-dose vitamin D supplementation in older Australians. We have published detailed trial methods and baseline characteristics ${ }^{4}$ and a statistical analysis plan for the primary and secondary outcomes of the trial. ${ }^{6}$ Using the Australian electoral roll as a sampling frame, we invited 421,207 people aged 60-79 years to participate. We also sought volunteers. People were not eligible if they self-reported a history of osteomalacia, sarcoidosis, hyperparathyroidism, hypercalcemia, or kidney stones, or if they reported taking supplementary vitamin $\mathrm{D}$ at a daily dose exceeding $500 \mathrm{IU}$. We randomised 21,315 people in a 1:1 ratio to receive either $60,000 \mathrm{IU}$ of cholecalciferol (vitamin $\mathrm{D}_{3}$ ) or placebo on the first day of each month for five years. Randomisation occurred between February 2014 and May 2015, and was undertaken within strata of age $(60-64 ; 65-69 ; 70-74 ; 75+$ years $)$, sex, and state of residence (New South Wales, Queensland, South Australia, Tasmania, Victoria, Western Australia) at baseline. The primary outcome is all-cause mortality and the secondary outcomes are total cancer incidence and colorectal cancer incidence; these will be ascertained via future linkage to death and cancer registries. The QIMR Berghofer Medical Research Institute Human Research Ethics Committee approved the 
medRxiv preprint doi: https://doi.org/10.1101/2020.08.23.20180422; this version posted August 25, 2020. The copyright holder for this preprint (which was not certified by peer review) is the author/funder, who has granted medRxiv a license to display the preprint in It is made available under a CC-BY-NC-ND 4.0 International license .

trial and all participants gave written or online consent to participate. All participants completed the intervention phase by $1^{\text {st }}$ February 2020.

\section{Data collection}

\section{Baseline survey}

Participants completed a survey at baseline that included questions about factors that we had previously shown to predict serum $25(\mathrm{OH}) \mathrm{D}$ concentration. ${ }^{7}$ We used self-reported height and weight to calculate body mass index $\left(\mathrm{BMI}, \mathrm{kg} / \mathrm{m}^{2}\right)$. To capture information on skin phenotype, we asked people to report how much their skin would tan if they spent several weeks outdoors in the sun in summer. We used data about living arrangements to derive an indicator of whether or not the person was living alone. Participants were asked to rate their quality of life (QoL) on a five-point scale, ranging from poor to excellent. We asked about smoking history, alcohol consumption and physical activity, which was used to calculate typical energy expenditure as metabolic equivalent tasks (METs) per week. Data on the amount of time spent outdoors between 9 am and $4 \mathrm{pm}$ on each day of the previous week was used to estimate total hours of sun exposure. Participants were asked to document their use of vitamin D supplements and intake of vitamin D-rich foods (using a pre-specified list of vitamin D-rich foods) in the previous month. We used AUSNUT 2007 and food/supplement composition details supplied by manufacturers to calculate total daily intake of vitamin $\mathrm{D}$ from diet and supplements in IU. The groups into which we categorised these variables are shown in Table 1.

\section{Annual surveys}

Every 12 months all participants were asked to complete a survey, including those who had withdrawn from the trial. These surveys asked people to rate their QoL using the same five-point scale from the baseline survey. Annual surveys 1, 3 and 5 asked about current weight, allowing us to calculate updated measures of BMI at three points in time. Every annual survey asked questions about the use of supplements containing vitamin D. We used this information to estimate daily intake of vitamin D from off-trial supplements for each year of the intervention.

\section{Use of off-trial supplements}

To be eligible for the trial, people had to report taking < 500 IU/day vitamin D from supplements. Following randomisation, participants were permitted to increase their daily intake of non-trial supplements up to a maximum of 2,000 IU and still remain in the trial. In addition to capturing supplement use via annual surveys, we also requested that people contact us by phone or online to report any changes to their intake of off-trial supplementary vitamin D.

\section{Blood questionnaire}

From August 2017, people who gave a blood sample were also asked to complete an additional questionnaire (hereafter called the 'blood questionnaire'). Using the same wording as at baseline, we asked people to report their skin tanning ability, physical activity, and time spent outdoors during the week prior to having blood taken.

\section{Ambient ultraviolet radiation}

Ambient ultraviolet (UV) radiation estimates were obtained from the Ozone Monitoring Instrument (OMI) satellite data. ${ }^{8}$ We obtained erythemally weighted average daily UV radiation from the OMUVB product from January 2012 to December 2017. To obtain an estimate of ambient UV radiation at a participant's place of residence at baseline or time of blood collection, we mapped participants' residential postcodes to a $1^{\circ}$ latitude by $1^{\circ}$ longitude grid. We then mapped this to calendar month-specific average erythemal daily doses. For blood samples collected from 2018 onwards, we used monthly averages from 2017.

\section{Measurement of serum 25(OH)D concentration}

To monitor differences in 25(OH)D distributions between the trial arms, we measured serum $25(\mathrm{OH}) \mathrm{D}$ concentrations in a random sample of people. Each year, starting one year after baseline, approximately 350 people from each trial arm received with their annual survey an invitation to provide a blood sample. Those who consented were instructed to attend their local pathology 
medRxiv preprint doi: https://doi.org/10.1101/2020.08.23.20180422; this version posted August 25, 2020. The copyright holder for this preprint (which was not certified by peer review) is the author/funder, who has granted medRxiv a license to display the preprint in

It is made available under a CC-BY-NC-ND 4.0 International license .

collection centre; a fasting blood sample was collected and sent by courier to our laboratory for initial processing. Samples were collected between March 2015 and February 2020. The 25(OH)D assay was performed using a tandem liquid chromatography mass spectroscopy assay at Metabolomics Australia at the University of Western Australia (a participant in the international Vitamin D Standardization Program). ${ }^{9,10}$

\section{Data management}

\section{Training and validation datasets}

In the current study we used data and serum $25(\mathrm{OH}) \mathrm{D}$ concentrations from the subset of participants who gave a blood sample and were randomised to the placebo arm of the study (maintaining blinding; see below). We partitioned this dataset into training (80\%) and validation (20\%) datasets. We derived our prediction models in the training dataset and then tested their performance in the validation dataset (details below). A small number of people (11.6\%) provided more than one blood sample over the course of the intervention; we ensured that repeated measures from a participant were all allocated to either the training or the validation dataset.

Since blood samples were collected throughout the year we deseasonalised serum 25(OH)D concentrations to account for seasonal variations. We first fitted a sinusoidal model to the measured serum 25(OH)D concentrations (where the sine and cos terms were functions of month of blood collection), and then added the overall mean serum $25(\mathrm{OH}) \mathrm{D}$ concentration to the residuals from the sinusoidal model. We dichotomised the deseasonalised serum $25(\mathrm{OH}) \mathrm{D}$ concentrations using cutpoints of $50 \mathrm{nmol} / \mathrm{L}, 60 \mathrm{nmol} / \mathrm{L}$ and $75 \mathrm{nmol} / \mathrm{L}$, with lower $(<)$ concentrations in each case being the outcome of interest. The Institute of Medicine in the United States concluded that $50 \mathrm{nmol} / \mathrm{L}$ is sufficient to ensure bone health in almost all people, ${ }^{11}$ and this is the minimum concentration recommended by The Royal College of Pathologists of Australasia. ${ }^{12}$ We used the cut-point of 75 $\mathrm{nmol} / \mathrm{L}$ because it is the target concentration recommended by The Endocrine Society ${ }^{13}$ it is also the approximate median of our measured serum $25(\mathrm{OH}) \mathrm{D}$ concentrations. The intermediate cut-point of $60 \mathrm{nmol} / \mathrm{L}$, the approximate first quartile, was included primarily so that we could evaluate how model performance varied with changing cut-points, and because the number $<50 \mathrm{nmol} / \mathrm{L}$ is potentially too low for effective subgroup analyses. The small number of measured serum $25(\mathrm{OH}) \mathrm{D}$ concentrations $<30 \mathrm{nmol} / \mathrm{L}$ precluded the use of this as a cut-point.

The dataset included thirteen predictors, four of which were ascertained at baseline only (sex, alcohol consumption, current smoker, and living alone). Tanning ability, physical activity, and time outdoors were taken primarily from the blood questionnaire, which we started asking participants to complete sixteen months after we commenced blood collection. If tanning ability was missing, we used the response at baseline. For people who provided a blood sample at year one (prior to the instigation of the blood questionnaire), we used their levels of physical activity and time outdoors as reported on the baseline survey under the assumption that behaviour would be similar over that time frame. We derived QoL and BMI from the annual survey response prior to the date of blood collection. Since we did not ask about weight on the second or fourth annual surveys, we estimated BMI at these times as follows: if a participant's BMI in the years prior and subsequent to the year in which they gave blood differed by $<5 \mathrm{~kg} / \mathrm{m}^{2}$, we used the average of those values; if we didn't have values for both years, or the difference was $\geq 5 \mathrm{~kg} / \mathrm{m}^{2}$, we left BMI missing. To calculate total daily intake of vitamin D, we estimated daily intake from supplements using the annual survey that was completed at the time of blood collection, and added this to the reported dietary intake from the baseline survey. We determined the month and participant's age category at the time of blood collection. Ambient UV radiation was assigned based on the month and place of residence at the time blood was collected. Supplementary Figure 1 summarises the sources of predictor variables and the timing of their ascertainment relative to the time of blood collection.

\section{Maintenance of blinding}

To remain blinded to treatment allocation, D-Health researchers did not have access to participants' serum $25(\mathrm{OH}) \mathrm{D}$ concentration data. Instead, an external researcher with access to the $25(\mathrm{OH}) \mathrm{D}$ data prepared our dataset. They identified which group was receiving the placebo by inspecting summary statistics for serum $25(\mathrm{OH}) \mathrm{D}$ concentrations within study arms. The subset of data for the placebo 
medRxiv preprint doi: https://doi.org/10.1101/2020.08.23.20180422; this version posted August 25, 2020. The copyright holder for this preprint (which was not certified by peer review) is the author/funder, who has granted medRxiv a license to display the preprint in

It is made available under a CC-BY-NC-ND 4.0 International license.

group, including serum $25(\mathrm{OH}) \mathrm{D}$ concentration and all potential predictor variables, was then returned to the D-Health team without the randomisation code or the participant identification codes included.

\section{Data analysis}

\section{Model fitting}

We fitted boosted regression tree (BRT) $)^{14-16}$ models to dichotomised deseasonalised serum $25(\mathrm{OH}) \mathrm{D}$ concentrations (i.e. used a Bernoulli loss function) for 36 combinations of parameter settings (learning rates of 0.01, 0.005 and 0.001 ; tree complexities of 2, 3, 4 and 5; and bag fractions of 0.5, 0.6 and 0.7). We used 10-fold cross-validation to determine the optimal number of trees for each choice of parameters. As recommended ${ }^{14}$ we discarded parameter combinations for which optimal prediction required fewer than 1000 trees. The model with minimum cross-validated deviance was selected as the final model.

\section{Assessing the effect of predictors}

We estimated the relative contributions of predictors to the final model. For each predictor, we generated a partial dependence plot, showing the marginal effect of the predictor on the response $;{ }^{15}$ these are created by first "averaging" out the effect of all predictors except the one of interest, and then plotting the average fitted value (i.e. the fitted function) against the predictor of interest.

\section{Evaluation using the validation dataset}

To evaluate each model's performance, we used it to generate predictions for the validation dataset. We plotted the receiver operating characteristic (ROC) curve, calculated the area under the ROC curve (AUC) and used bootstrapping to estimate a 95\% confidence interval (CI) for the AUC. We assessed calibration by plotting observed prevalences against the predicted probabilities for predicted probability ranges defined by deciles. We also calculated the root-mean-squared error (RMSE).

For each model, we plotted sensitivity, specificity, positive predictive value (PPV) and negative predictive value (NPV) versus probability thresholds (used to dichotomise the predictions). We identified the optimal probability threshold using the Youden index, and estimated the PPV, and NPV, and their 95\% Agresti-Coull CIs. ${ }^{17}$

\section{Predictions for all D-Health participants}

We applied the final models to baseline data for all trial participants to predict the probability that each person's deseasonalised baseline serum $25(\mathrm{OH}) \mathrm{D}$ concentration was $<50 \mathrm{nmol} / \mathrm{L},<60 \mathrm{nmol} / \mathrm{L}$, and $<75 \mathrm{nmol} / \mathrm{L}$ prior to taking any study tablets. We dichotomised the predictions using the optimal probability threshold identified using the validation dataset.

\section{Software}

We used SAS version 9.4 (SAS Institute, Inc, Cary, NC) to construct datasets, and to produce summary statistics. R version 3.6.1 was used to fit BRTs, to generate deseasonalised predictions for all D-Health participants, and to produce figures. ${ }^{18}$ We used the gbm package ${ }^{19}$ and additional scripts that were developed for fitting BRTs (gbm.step, gbm.plot, gbm.interactions) ${ }^{14}$ We used the ROCR, ${ }^{20}$ $\mathrm{pROC}^{21}$ and modEvA ${ }^{22}$ packages to evaluate models, and the OptimalCutpoints ${ }^{23}$ package to determine the probability threshold to use for dichotomising predictions.

\section{Role of the funding source}

The funder of the study had no role in study design, data collection, data analysis, data interpretation, or writing of the report.

\section{RESULTS}

\section{Measured serum 25(OH)D concentrations}

After excluding one record with an extreme serum $25(\mathrm{OH}) \mathrm{D}$ concentration $(265 \mathrm{nmol} / \mathrm{L})$, the dataset of serum $25(\mathrm{OH}) \mathrm{D}$ concentrations from people randomised to placebo included 2235 observations 
medRxiv preprint doi: https://doi.org/10.1101/2020.08.23.20180422; this version posted August 25, 2020. The copyright holder for this preprint (which was not certified by peer review) is the author/funder, who has granted medRxiv a license to display the preprint in

It is made available under a CC-BY-NC-ND 4.0 International license.

from 1986 people. Most people $(\mathrm{N}=1755(88.4 \%))$ provided one blood sample only; $213(10.7 \%)$ and $18(0.9 \%)$ people provided two and three blood samples, respectively.

The mean serum 25(OH)D concentration was $77.4 \mathrm{nmol} / \mathrm{L}$ (standard deviation (SD) $24.9 \mathrm{nmol} / \mathrm{L}$ ) (Supplementary Figure 2A). Thirteen percent $(\mathrm{n}=291), 24.2 \%(\mathrm{n}=541)$ and $48.3 \%(\mathrm{n}=1079)$ of samples had serum 25(OH)D concentrations $<50 \mathrm{nmol} / \mathrm{L},<60 \mathrm{nmol} / \mathrm{L}$, and $<75 \mathrm{nmol} / \mathrm{L}$, respectively; only $2.0 \%(\mathrm{n}=44)$ had concentrations $<30 \mathrm{nmol} / \mathrm{L}$. Deseasonalising the data reduced slightly the variability in concentrations (SD $23.6 \mathrm{nmol} / \mathrm{L}$ ) and the percentage with concentrations $<50$ $\mathrm{nmol} / \mathrm{L}$ (Supplementary Figure 2B); 10.7\%, 23.6\%, and 48.9\% of deseasonalised concentrations were $<50 \mathrm{nmol} / \mathrm{L},<60 \mathrm{nmol} / \mathrm{L}$, and $<75 \mathrm{nmol} / \mathrm{L}$, respectively.

\section{Training and validation data}

The training and validation datasets had 1788 and 447 samples, respectively. Table 1 shows the distribution of deseasonalised serum $25(\mathrm{OH}) \mathrm{D}$ concentration for all participants and by levels of predictor variables. The datasets had very similar percentages of samples with 'lower' deseasonalised serum $25(\mathrm{OH}) \mathrm{D}$ concentrations (training: $10.5 \%<50 \mathrm{nmol} / \mathrm{L}, 23.1 \%<60 \mathrm{nmol}$, and $48.8<75$ $\mathrm{nmol} / \mathrm{L}$; validation: $11.9 \%<50 \mathrm{nmol} / \mathrm{L}, 25.7 \%<60 \mathrm{nmol} / \mathrm{L}$, and $49.2 \%<75 \mathrm{nmol} / \mathrm{L})$.

Table 1. Summary statistics for deseasonalised serum 25(OH)D concentration for all participants and by levels of predictor variables in the training and validation datasets.

\begin{tabular}{|c|c|c|c|c|c|c|c|c|c|c|}
\hline \multirow[b]{4}{*}{ Predictor variable } & & & \multicolumn{8}{|c|}{ Deseasonalised serum 25(OH)D concentration (nmoh) } \\
\hline & & & \multicolumn{4}{|c|}{ Training dataset $(\mathrm{N}=1788)$} & \multicolumn{4}{|c|}{ Validation dataset $(N=447)$} \\
\hline & \multicolumn{2}{|c|}{$\mathbf{N}(\%)^{1}$} & \multirow[b]{2}{*}{ Mean (SD) } & \multicolumn{3}{|c|}{$\%$} & \multirow[b]{2}{*}{ Mean (SD) } & \multicolumn{3}{|c|}{$\%$} \\
\hline & Training & Validation & & $\begin{array}{c}<50 \\
\text { nmohL }\end{array}$ & $\begin{array}{c}<60 \\
\text { nmoh }\end{array}$ & $\begin{array}{c}<75 \\
\text { nmohL }\end{array}$ & & $\begin{array}{c}<50 \\
\text { nmohL }\end{array}$ & $\begin{array}{c}<60 \\
\mathrm{nmoh}\end{array}$ & $\begin{array}{c}<75 \\
\text { nmolh }\end{array}$ \\
\hline \multicolumn{11}{|l|}{ Age (years) } \\
\hline$<70$ & $615(34.4)$ & $166(37.1)$ & $78.5(23.3)$ & 10.1 & 21.3 & 46.0 & $80.3(25.0)$ & 12.0 & 20.5 & 44.0 \\
\hline 70 to $<75$ & $494(27.6)$ & $125(28.0)$ & $77.9(24.4)$ & 9.9 & 23.1 & 48.6 & $78.5(22.8)$ & 13.6 & 24.0 & 46.4 \\
\hline$\geq 75$ & $679(38.0)$ & $156(34.9)$ & $75.9(23.1)$ & 11.2 & 24.7 & 51.4 & $74.0(22.9)$ & 10.3 & 32.7 & 57.1 \\
\hline \multicolumn{11}{|l|}{ Sex } \\
\hline Men & $901(50.4)$ & $223(49.9)$ & $76.4(22.9)$ & 10.2 & 23.9 & 51.8 & $76.5(23.5)$ & 12.1 & 27.8 & 52.9 \\
\hline Women & $887(49.6)$ & $224(50.1)$ & $78.3(24.1)$ & 10.7 & 22.3 & 45.7 & $78.7(24.0)$ & 11.6 & 23.7 & 45.5 \\
\hline \multicolumn{11}{|l|}{ Month } \\
\hline January & $170(9.5)$ & $29(6.5)$ & $73.7(20.8)$ & 11.8 & 22.9 & 55.9 & $74.7(24.4)$ & 13.8 & 37.9 & 55.2 \\
\hline February & 178 (10.0) & $36(8.1)$ & $80.5(24.5)$ & 7.3 & 21.3 & 42.7 & $76.0(16.3)$ & 2.8 & 16.7 & 50.0 \\
\hline March & $152(8.5)$ & $47(10.5)$ & $77.6(24.9)$ & 11.2 & 23.0 & 47.4 & $76.1(20.6)$ & 12.8 & 21.3 & 53.2 \\
\hline April & $152(8.5)$ & $38(8.5)$ & 77.7 (27.9) & 12.5 & 25.7 & 52.0 & $69.7(21.5)$ & 18.4 & 28.9 & 76.3 \\
\hline May & 185 (10.3) & $50(11.2)$ & $80.9(25.3)$ & 9.2 & 23.2 & 42.2 & $82.6(27.3)$ & 12.0 & 22.0 & 44.0 \\
\hline June & $176(9.8)$ & $31(6.9)$ & $75.7(26.2)$ & 15.9 & 27.3 & 54.0 & $76.6(28.6)$ & 25.8 & 35.5 & 48.4 \\
\hline July & $155(8.7)$ & $49(11.0)$ & $72.9(23.3)$ & 15.5 & 29.0 & 54.2 & $75.0(23.8)$ & 16.3 & 28.6 & 55.1 \\
\hline August & $134(7.5)$ & $30(6.7)$ & $77.9(21.3)$ & 9.0 & 23.9 & 45.5 & $74.9(24.1)$ & 13.3 & 33.3 & 46.7 \\
\hline September & $141(7.9)$ & $45(10.1)$ & $79.2(21.5)$ & 8.5 & 16.3 & 47.5 & $81.6(27.1)$ & 11.1 & 26.7 & 44.4 \\
\hline October & $139(7.8)$ & $40(8.9)$ & $77.6(22.2)$ & 9.4 & 23.0 & 48.2 & $83.7(24.4)$ & 2.5 & 20.0 & 32.5 \\
\hline November & $133(7.4)$ & $33(7.4)$ & 75.5 (19.6) & 7.5 & 21.1 & 49.6 & $80.2(22.5)$ & 6.1 & 21.2 & 39.4 \\
\hline December & $73(4.1)$ & $19(4.3)$ & $79.4(18.9)$ & 2.7 & 15.1 & 43.8 & $77.6(17.6)$ & 5.3 & 21.1 & 42.1 \\
\hline \multicolumn{11}{|c|}{ Ambient ultraviolet irradiation $\left(\mathrm{J} / \mathrm{m}^{2}\right)^{2}$} \\
\hline$<1250$ & $315(17.6)$ & $84(18.8)$ & $72.3(24.5)$ & 17.1 & 31.7 & 58.1 & $73.6(25.2)$ & 21.4 & 34.5 & 54.8 \\
\hline 1250 to $<2500$ & $437(24.4)$ & 107 (23.9) & $79.7(23.8)$ & 9.2 & 21.1 & 43.9 & $78.7(27.1)$ & 14.0 & 27.1 & 49.5 \\
\hline 2500 to $<3750$ & 285 (15.9) & $81(18.1)$ & $77.5(24.7)$ & 11.2 & 23.9 & 50.5 & $78.9(23.4)$ & 8.6 & 21.0 & 50.6 \\
\hline 3750 to $<5000$ & $262(14.7)$ & $77(17.2)$ & $77.6(22.4)$ & 9.5 & 21.8 & 46.2 & $77.7(20.6)$ & 6.5 & 24.7 & 46.8 \\
\hline$\geq 5000$ & 489 (27.3) & 98 (21.9) & $78.3(22.2)$ & 7.4 & 19.6 & 47.4 & $78.6(21.3)$ & 8.2 & 21.4 & 44.9 \\
\hline
\end{tabular}


medRxiv preprint doi: https://doi.org/10.1101/2020.08.23.20180422; this version posted August 25, 2020. The copyright holder for this preprint (which was not certified by peer review) is the author/funder, who has granted medRxiv a license to display the preprint in It is made available under a CC-BY-NC-ND 4.0 International license .

\begin{tabular}{|c|c|c|c|c|c|c|c|c|c|c|}
\hline \multirow[b]{4}{*}{ Predictor variable } & & & \multicolumn{8}{|c|}{ Deseasonalised serum 25(OH)D concentration (nmoL) } \\
\hline & \multirow{2}{*}{\multicolumn{2}{|c|}{$\mathbf{N}(\%)^{1}$}} & \multicolumn{4}{|c|}{ Training dataset $(\mathbf{N}=1788)$} & \multicolumn{4}{|c|}{ Validation dataset $(\mathrm{N}=447)$} \\
\hline & & & \multirow[b]{2}{*}{ Mean (SD) } & \multicolumn{3}{|c|}{$\%$} & \multirow[b]{2}{*}{ Mean (SD) } & \multicolumn{3}{|c|}{$\%$} \\
\hline & Training & Validation & & $\begin{array}{c}<50 \\
\text { nmohL }\end{array}$ & $\begin{array}{c}<60 \\
\text { nmohL }\end{array}$ & $\begin{array}{c}<75 \\
\text { nmolh }\end{array}$ & & $\begin{array}{c}<50 \\
\text { nmohL }\end{array}$ & $\begin{array}{c}<60 \\
\text { nmohL }\end{array}$ & $\begin{array}{c}<75 \\
\text { nmohL }\end{array}$ \\
\hline \multicolumn{11}{|c|}{ Physical activity (METs/week) } \\
\hline Low $(<18)$ & $350(28.7)$ & $95(30.4)$ & $77.1(25.1)$ & 15.1 & 26.0 & 48.0 & $76.8(25.5)$ & 15.8 & 27.4 & 45.3 \\
\hline Moderate $(18$ to < 45) & $449(36.8)$ & $107(34.3)$ & $77.8(21.4)$ & 7.1 & 20.9 & 46.1 & $80.9(22.9)$ & 7.5 & 18.7 & 43.9 \\
\hline High $(\geq 45)$ & $420(34.5)$ & $110(35.3)$ & $80.6(23.0)$ & 6.7 & 17.4 & 44.3 & $80.9(26.0)$ & 10.9 & 21.8 & 45.5 \\
\hline \multicolumn{11}{|c|}{ Time outdoors (hours/week) } \\
\hline$<5$ & $292(23.7)$ & $75(24.1)$ & $76.7(25.2)$ & 15.8 & 25.3 & 47.6 & $76.2(25.2)$ & 14.7 & 29.3 & 50.7 \\
\hline 5 to $<10$ & $274(22.3)$ & $52(16.7)$ & $77.0(21.6)$ & 9.1 & 22.3 & 46.7 & $79.0(23.0)$ & 9.6 & 23.1 & 42.3 \\
\hline 10 to $<15$ & $237(19.3)$ & $63(20.3)$ & $76.9(23.2)$ & 9.3 & 24.1 & 49.4 & $78.0(23.2)$ & 9.5 & 20.6 & 47.6 \\
\hline 15 to $<25$ & $264(21.5)$ & $59(19.0)$ & $80.4(23.1)$ & 6.8 & 17.8 & 44.3 & $82.9(28.2)$ & 13.6 & 20.3 & 42.4 \\
\hline$\geq 25$ & $163(13.3)$ & $62(19.9)$ & $84.1(22.9)$ & 3.1 & 13.5 & 39.9 & $82.6(23.6)$ & 8.1 & 17.7 & 38.7 \\
\hline \multicolumn{11}{|l|}{ Tan moderately or deeply } \\
\hline No & $593(33.3)$ & 147 (33.3) & $74.7(24.4)$ & 14.2 & 27.3 & 54.0 & $74.7(22.7)$ & 15.0 & 29.3 & 52.4 \\
\hline Yes & $1188(66.7)$ & $295(66.7)$ & $78.7(23.1)$ & 8.7 & 21.0 & 46.4 & $79.1(24.2)$ & 10.2 & 24.1 & 47.8 \\
\hline \multicolumn{11}{|l|}{ Body mass index $\left(\mathrm{kg} / \mathrm{m}^{2}\right)$} \\
\hline$<25$ & $563(32.6)$ & $129(30.3)$ & $80.5(24.9)$ & 9.6 & 20.2 & 42.8 & $81.8(23.6)$ & 9.3 & 21.7 & 39.5 \\
\hline 25 to $<30$ & $717(41.5)$ & $194(45.5)$ & $77.3(22.2)$ & 8.5 & 22.6 & 49.8 & $76.2(23.5)$ & 11.3 & 26.3 & 52.6 \\
\hline$\geq 30$ & $449(26.0)$ & $103(24.2)$ & $73.2(23.5)$ & 14.5 & 28.3 & 55.2 & $75.3(23.2)$ & 13.6 & 27.2 & 55.3 \\
\hline \multicolumn{11}{|c|}{ Alcohol consumption (drinks/week) } \\
\hline$<1.0$ & $442(25.8)$ & $136(30.8)$ & $76.2(24.8)$ & 11.3 & 25.3 & 53.4 & $74.6(22.8)$ & 12.5 & 31.6 & 54.4 \\
\hline $1.0-2.0$ & $261(15.2)$ & $72(16.3)$ & $76.4(21.5)$ & 9.2 & 23.4 & 49.4 & $75.8(23.6)$ & 16.7 & 26.4 & 55.6 \\
\hline $2.1-7.0$ & $499(29.1)$ & $114(25.9)$ & $77.5(23.3)$ & 10.6 & 23.0 & 49.1 & $77.2(24.5)$ & 16.7 & 26.3 & 49.1 \\
\hline $7.1-14.0$ & 320 (18.6) & $78(17.7)$ & 79.3 (22.9) & 8.4 & 20.0 & 43.8 & $80.0(21.3)$ & 3.8 & 19.2 & 42.3 \\
\hline$>14.0$ & $194(11.3)$ & $41(9.3)$ & $79.0(24.8)$ & 11.3 & 21.1 & 44.3 & $85.9(26.9)$ & 2.4 & 17.1 & 39.0 \\
\hline \multicolumn{11}{|l|}{ Current smoker } \\
\hline No & $1716(96.7)$ & $426(96.4)$ & $77.6(23.1)$ & 9.8 & 22.4 & 48.4 & 77.3 (23.4) & 11.7 & 25.8 & 50.0 \\
\hline Yes & $58(3.3)$ & $16(3.6)$ & $71.8(35.0)$ & 29.3 & 44.8 & 60.3 & $80.9(32.0)$ & 18.8 & 31.3 & 43.8 \\
\hline \multicolumn{11}{|l|}{ Living alone } \\
\hline No & $1438(81.0)$ & $376(84.1)$ & $77.6(22.9)$ & 9.7 & 22.0 & 48.7 & $78.0(23.6)$ & 11.7 & 25.0 & 48.7 \\
\hline Yes & $338(19.0)$ & $71(15.9)$ & $76.1(25.5)$ & 13.6 & 27.2 & 48.5 & $75.5(24.5)$ & 12.7 & 29.6 & 52.1 \\
\hline \multicolumn{11}{|l|}{ Self-rated quality of life } \\
\hline Excellent & $469(26.4)$ & $113(25.5)$ & $78.0(22.3)$ & 7.0 & 21.5 & 49.5 & $79.1(24.6)$ & 11.5 & 25.7 & 50.4 \\
\hline Very good & $823(46.3)$ & $224(50.5)$ & $77.9(23.0)$ & 10.2 & 22.1 & 47.0 & $76.1(23.4)$ & 12.5 & 25.9 & 49.1 \\
\hline Good, fair or poor & $484(27.3)$ & $107(24.1)$ & $76.0(25.5)$ & 14.0 & 26.0 & 51.0 & $79.2(23.3)$ & 10.3 & 25.2 & 47.7 \\
\hline \multicolumn{11}{|c|}{ Total intake of vitamin D (IU/day) ${ }^{3}$} \\
\hline$<100$ & $301(16.9)$ & $97(21.7)$ & $72.9(22.1)$ & 15.0 & 27.9 & 57.1 & 73.7 (22.0) & 15.5 & 33.0 & 50.5 \\
\hline 100 to $<200$ & 708 (39.8) & $181(40.6)$ & $74.8(23.0)$ & 13.0 & 28.0 & 53.2 & $74.9(24.0)$ & 14.9 & 29.3 & 54.7 \\
\hline 200 to $<500$ & $434(24.4)$ & $97(21.7)$ & $76.6(23.5)$ & 8.8 & 22.4 & 49.5 & $77.6(23.1)$ & 8.2 & 24.7 & 52.6 \\
\hline$\geq 500$ & $334(18.8)$ & $71(15.9)$ & $87.9(23.1)$ & 2.7 & 9.3 & 30.8 & $90.1(22.9)$ & 4.2 & 8.5 & 28.2 \\
\hline \multicolumn{11}{|c|}{$\begin{array}{l}{ }^{1} \text { Each observation corresponds to a single blood sample. Training dataset: } 1408,166 \text {, and } 16 \text { people provided one, two and three blood } \\
\text { samples respectively. Validation dataset: } 347,47 \text {, and } 2 \text { people provided one, two and three blood samples respectively. Missing data in the } \\
\text { training dataset: physical activity, } 569 \text {; time outdoors, } 558 \text {; tanning ability, } 7 \text {; body mass index, } 59 \text {; alcohol consumption, } 72 \text {; current } \\
\text { smoker, } 14 \text {; living alone, } 12 \text {; self-rated quality of life, } 12 \text {; total intake of vitamin D, } 11 \text {. Missing data in the validation dataset: physical } \\
\text { activity, } 135 \text {; time outdoors, } 136 \text {; tanning ability, } 5 \text {; body mass index, } 21 \text {; alcohol consumption, } 6 \text {; current smoker, } 5 \text {; self-rated quality of } \\
\text { life, } 3 \text {; total intake of vitamin D, } 1 .{ }^{2} \text { Month-specific average erythemal daily dose at time of blood draw. It is included as a continuous } \\
\text { variables in boosted regression tree models. For simplicity, we have presented summary statistics within categories of ultraviolet irradiation. } \\
{ }^{3} \text { Sum of intake from diet and supplements. } \\
\text { Abbreviations: IU, international units; MET, metabolic equivalent of task; SD, standard deviation. }\end{array}$} \\
\hline
\end{tabular}


medRxiv preprint doi: https://doi.org/10.1101/2020.08.23.20180422; this version posted August 25, 2020. The copyright holder for this preprint (which was not certified by peer review) is the author/funder, who has granted medRxiv a license to display the preprint in It is made available under a CC-BY-NC-ND 4.0 International license .

\section{Final parameter settings}

The models for $<50 \mathrm{nmol} / \mathrm{L},<60 \mathrm{nmol} / \mathrm{L}$, and $<75 \mathrm{nmol} / \mathrm{L}$ used tree complexities of 5, 2, and 5 , respectively, learning rates of $0.001,0.001$, and 0.005 , respectively, and bag fractions of $0.5,0.5$, and 0.6 , respectively, and their cross-validated deviance was minimised using 3850,3850, and 1000 trees (Supplementary Tables 1 to 3 ).

\section{Associations with predictors}

The two most influential predictors in all models were ambient UV radiation and total intake of vitamin $\mathrm{D}$ from food and supplements (Table 2). The interaction between these two variables was always amongst the top two strongest two-way interactions (Supplementary Table 4). Partial dependency plots for these predictors are shown in Figure 1. As expected, the predicted probability of 'lower' serum $25(\mathrm{OH}) \mathrm{D}$ concentration decreased with increasing total intake of vitamin D. There was a non-linear relationship with increasing UV radiation, decreasing steeply before becoming relatively stable. Partial dependency plots for the predictors that were ranked $3^{\text {rd }}$ to $13^{\text {th }}$ (least) influential are shown in Supplementary Figures 3 to 5.

Table 2. Relative contributions (\%) of predictor variables in the boosted regression tree models for deseasonalised serum $25(\mathrm{OH}) \mathrm{D}$ concentration $<50 \mathrm{nmol} / \mathrm{L},<60 \mathrm{nmol} / \mathrm{L}$, and $<75 \mathrm{nmol} / \mathrm{L}$.

\begin{tabular}{|c|c|c|c|c|c|}
\hline \multicolumn{2}{|l|}{$<50 \mathrm{nmol} / \mathrm{L}$} & \multicolumn{2}{|l|}{$<60 \mathrm{nmol} / \mathrm{L}$} & \multicolumn{2}{|l|}{$<75 \mathrm{nmol} / \mathrm{L}$} \\
\hline Predictor variable & $\begin{array}{l}\text { RC } \\
\text { (\%) }\end{array}$ & Predictor variable & $\begin{array}{l}\mathbf{R C} \\
(\%)\end{array}$ & Predictor variable & $\begin{array}{l}\text { RC } \\
\text { (\%) }\end{array}$ \\
\hline Ambient UV radiation $^{1}$ & 21.6 & Total intake of vitamin $\mathrm{D}^{2}$ & 29.1 & Ambient UV radiation ${ }^{1}$ & 26.1 \\
\hline Total intake of vitamin $\mathrm{D}^{2}$ & 19.0 & Ambient UV radiation ${ }^{1}$ & 23.7 & Total intake of vitamin $D^{2}$ & 19.4 \\
\hline Time outdoors & 11.3 & Time outdoors & 10.3 & Alcohol consumption & 12.9 \\
\hline Alcohol consumption & 8.9 & Current smoker & 6.2 & Time outdoors & 9.6 \\
\hline BMI & 8.4 & QoL & 5.3 & $\mathrm{BMI}$ & 7.4 \\
\hline QoL & 6.9 & Alcohol consumption & 5.2 & Month of blood draw & 5.1 \\
\hline Physical activity & 6.0 & Physical activity & 4.2 & Physical activity & 4.5 \\
\hline Month of blood draw & 4.7 & Living alone & 4.2 & Tanning ability & 4.3 \\
\hline Current smoker & 4.5 & $\mathrm{BMI}$ & 4.2 & Age & 4.0 \\
\hline Tanning ability & 3.8 & Tanning ability & 3.8 & QoL & 2.6 \\
\hline Living alone & 1.9 & Month of blood draw & 1.8 & Sex & 1.6 \\
\hline Age & 1.7 & Age & 1.8 & Current smoker & 1.5 \\
\hline Sex & 1.2 & Sex & 0.4 & Living alone & 1.1 \\
\hline
\end{tabular}

${ }^{1}$ Month-specific average erythemal daily dose at time of blood draw. ${ }^{2}$ From diet and supplements

Abbreviations: BMI, body mass index; QoL, quality of life; RC, relative contribution; UV, ultraviolet 
medRxiv preprint doi: https://doi.org/10.1101/2020.08.23.20180422; this version posted August 25, 2020. The copyright holder for this preprint (which was not certified by peer review) is the author/funder, who has granted medRxiv a license to display the preprint in It is made available under a CC-BY-NC-ND 4.0 International license .

(A) $<50 \mathrm{nmol} / \mathrm{L}$
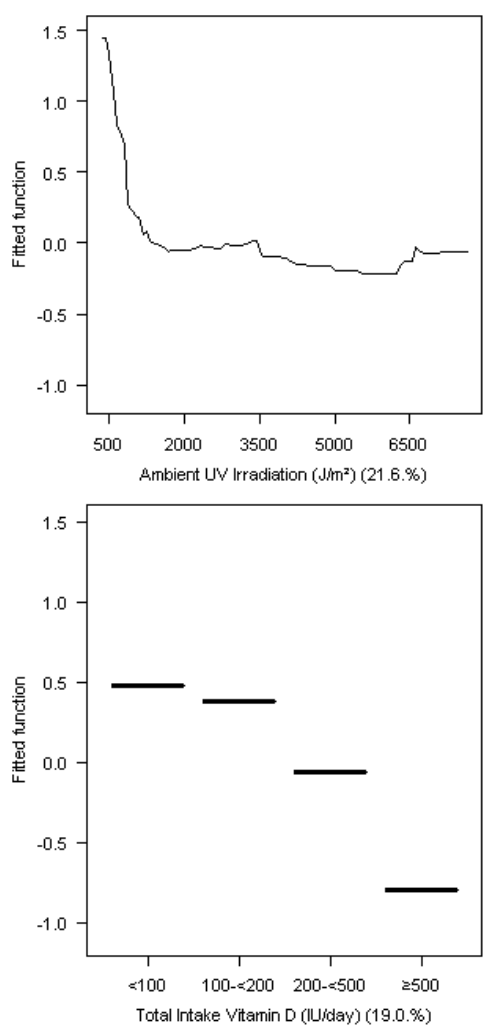

(B) $<60 \mathrm{nmol} / \mathrm{L}$
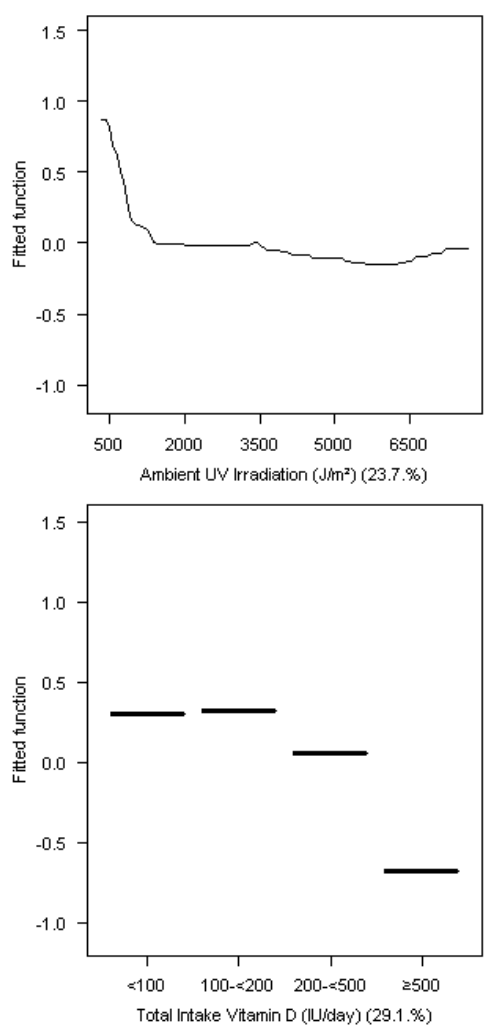

(C) $<75 \mathrm{nmol} / \mathrm{L}$
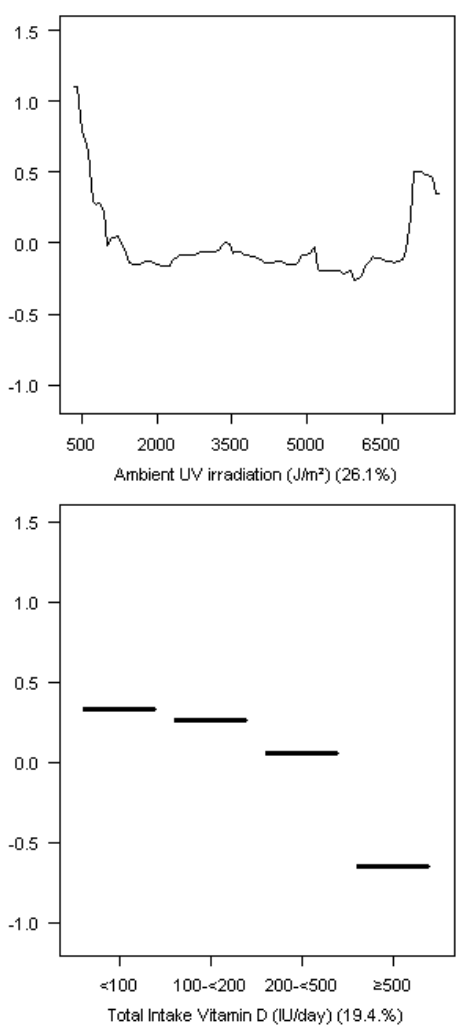

Figure 1. Partial dependence plots ${ }^{1}$ for the two most influential ${ }^{2}$ variables (ambient UV irradiation ${ }^{3}$ and total intake of vitamin $\left.\mathrm{D}^{4}\right)$ in the boosted regression tree models ${ }^{5}$ for deseasonalised serum $25(\mathrm{OH}) \mathrm{D}$ concentration $(\mathrm{A})<50 \mathrm{nmol} / \mathrm{L},(\mathrm{B})<60 \mathrm{nmol} / \mathrm{L}$, and $(\mathrm{C})<75 \mathrm{nmol} / \mathrm{L}$.

\footnotetext{
${ }^{1}$ Fitted functions have been centered by subtracting their mean. ${ }^{2}$ The relative contribution of each predictor variable is given in brackets. ${ }^{3}$ Month-specific average erythemal daily dose at time of blood draw. ${ }^{4}$ Sum of intake from diet and supplements. ${ }^{5}$ The models were fitted to a training dataset containing $\mathrm{n}=1788$ blood samples. The models for $<50 \mathrm{nmol} / \mathrm{L},<60 \mathrm{nmol} / \mathrm{L}$, and $<75 \mathrm{nmol} / \mathrm{L}$ used tree complexities of 5,2 , and 5 , respectively, learning rates of $0.001,0.001$, and 0.005 , respectively, and bag fractions of $0.5,0.5$, and 0.7 , respectively, and their cross-validated deviance was minimised using 3850, 3850, and 1000 trees, respectively.
}

\section{Evaluation using validation data}

The models for $<50 \mathrm{nmol} / \mathrm{L}$ and $<60 \mathrm{nmol} / \mathrm{L}$ had very similar discriminatory ability, with AUCs of 0.71 (95\% CI 0.63-0.78) and 0.70 (95\% CI 0.65-0.76), respectively (Figure 2). The AUC for the model predicting < $75 \mathrm{nmol} / \mathrm{L}$ was slightly lower $(0.66,95 \%$ CI $0.61-0.71)$. All models were reasonably well calibrated (Figure 3). The RMSE was $0.31,0.42$, and 0.48 for the models for $<50$ $\mathrm{nmol} / \mathrm{L},<60 \mathrm{nmol}$, and $<75 \mathrm{nmol} / \mathrm{L}$, respectively.

Supplementary Figure 6 shows the sensitivity, specificity, PPV, and NPV plotted against probability threshold for the model for $<50 \mathrm{nmol} / \mathrm{L}$. The model had very high NPV across a wide range of thresholds but its PPV was generally poor. Using the optimal threshold to dichotomise predictions, the NPV was excellent $(0.94,95 \%$ CI $0.90-0.96)$, the sensitivity $(0.64,95 \%$ CI $0.51-0.76)$ and specificity $(0.72,95 \%$ CI $0.70-0.76)$ were moderately good, and the PPV was poor $(0.23,95 \%$ CI $0.17-0.31$ ) (Table 3). Compared with the model for $<50 \mathrm{nmol} / \mathrm{L}$, the model for $<60 \mathrm{nmol} / \mathrm{L}$ had slightly better PPV, its NPV was very good, and its sensitivity and specificity were similar (Table 3 , Supplementary Figure 7). All performance measures for the model predicting $<75 \mathrm{nmol} / \mathrm{L}$ were between 0.62 and 0.65, inclusive (Table 3, Supplementary Figure 8). 
medRxiv preprint doi: https://doi.org/10.1101/2020.08.23.20180422; this version posted August 25, 2020. The copyright holder for this preprint (which was not certified by peer review) is the author/funder, who has granted medRxiv a license to display the preprint in It is made available under a CC-BY-NC-ND 4.0 International license .

(A) $<50 \mathrm{nmol} / \mathrm{L}$

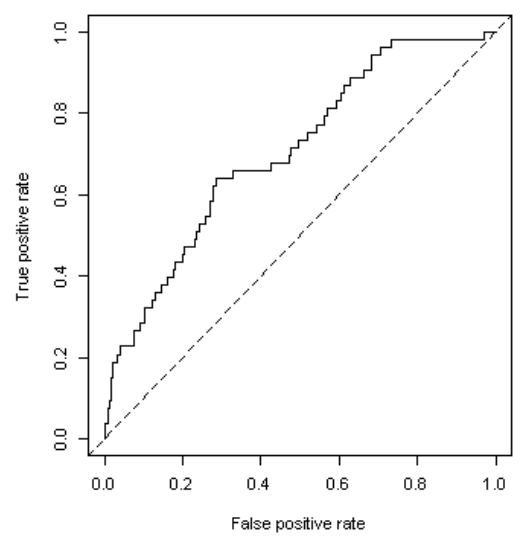

(B) $<60 \mathrm{nmol} / \mathrm{L}$

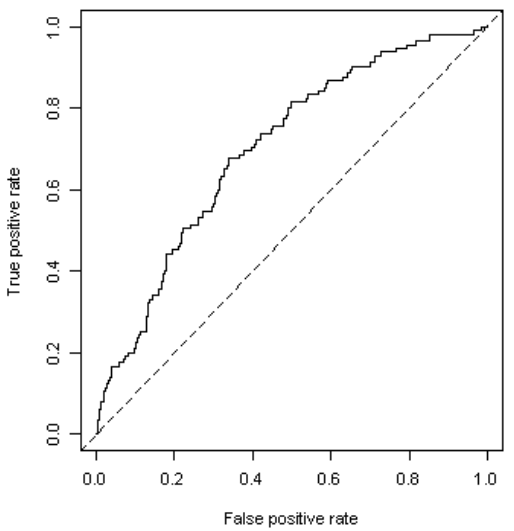

(C) $<75 \mathrm{nmol} / \mathrm{L}$

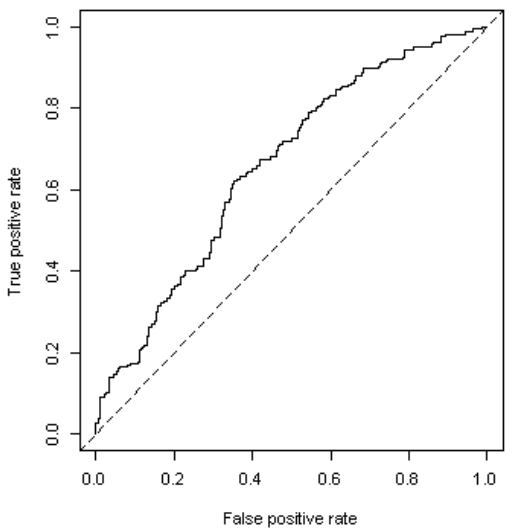

Figure 2. Receiver operating characteristic curves for the boosted regression tree models for deseasonalised serum $25(\mathrm{OH}) \mathrm{D}$ concentration $(\mathrm{A})<50 \mathrm{nmol} / \mathrm{L}$, (B) $<60 \mathrm{nmol} / \mathrm{L}$, and $(\mathrm{C})<$ $75 \mathrm{nmol} / \mathrm{L}$; models applied to the validation dataset $(\mathrm{n}=447)$.

(A) $<50 \mathrm{nmol} / \mathrm{L}$

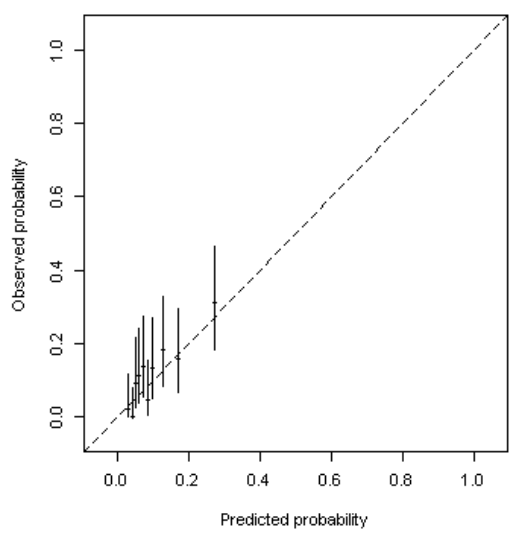

(B) $<60 \mathrm{nmol} / \mathrm{L}$

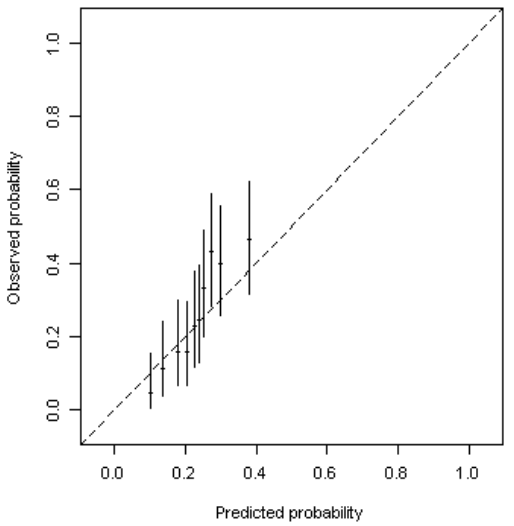

(C) $<75 \mathrm{nmol} / \mathrm{L}$

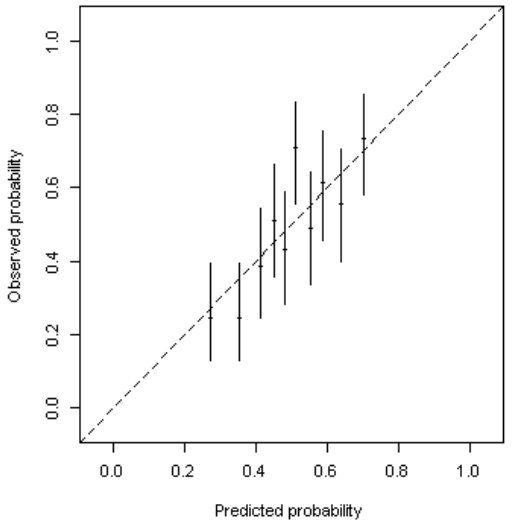

Figure 3. Calibration plots ${ }^{1}$ for the boosted regression tree models for deseasonalised serum $25(\mathrm{OH}) \mathrm{D}$ concentration (A) $<50 \mathrm{nmol} / \mathrm{L},(B)<60 \mathrm{nmol} / \mathrm{L}$, and $(\mathrm{C})<75 \mathrm{nmol} / \mathrm{L}$; models applied to the validation dataset $(n=447)$.

${ }^{1}$ Predicted probability ranges defined by deciles.

Table 3. Sensitivity, specificity, positive predictive value (PPV), and negative predictive value (NPV) of boosted regression tree models ${ }^{1}$ when predictions are dichotomised using the optimal thresholds $;^{2}$ values calculated using the validation dataset $(n=447)$.

\begin{tabular}{llcccc}
\hline Model $^{1}$ & $\begin{array}{l}\text { Probability } \\
\text { threshold }\end{array}$ & \multicolumn{4}{c}{ Estimate $(95 \% \mathrm{Cl})^{3}$} \\
\cline { 3 - 6 } & & Sensitivity & Specificity & PPV & NPV \\
\hline$<50 \mathrm{nmol} / \mathrm{L}$ & 0.103 & $0.642(0.507,0.757)$ & $0.716(0.669,0.758)$ & $0.233(0.172,0.308)$ & $0.937(0.904,0.959)$ \\
$<60 \mathrm{nmol} / \mathrm{L}$ & 0.244 & $0.678(0.588,0.757)$ & $0.663(0.610,0.711)$ & $0.411(0.343,0.482)$ & $0.856(0.808,0.894)$ \\
$<75 \mathrm{nmol} / \mathrm{L}$ & 0.501 & $0.623(0.557,0.684)$ & $0.648(0.583,0.707)$ & $0.631(0.565,0.693)$ & $0.639(0.575,0.698)$ \\
\hline
\end{tabular}

${ }^{1}$ Modelling deseasonalised serum 25(OH)D concentration $<50 \mathrm{nmol} / \mathrm{L},<60 \mathrm{nmol} / \mathrm{L}$, and $<75 \mathrm{nmol} / \mathrm{L}$. ${ }^{2}$ Value identified using the Youden index. ${ }^{3}$ CIs estimated using the method proposed by Agresti and Coull.

Abbreviation: CI, confidence interval.

\section{Predictions for all participants at baseline}

We applied the models to baseline data for all D-Health Trial participants and dichotomised predictions using the probability thresholds in Table 3. Using the model for $<50 \mathrm{nmol} / \mathrm{L}, 24.4 \%$ of people were predicted to have deseasonalised serum $25(\mathrm{OH}) \mathrm{D}$ concentration $<50 \mathrm{nmol} / \mathrm{L}$ prior to 
medRxiv preprint doi: https://doi.org/10.1101/2020.08.23.20180422; this version posted August 25, 2020. The copyright holder for this preprint (which was not certified by peer review) is the author/funder, who has granted medRxiv a license to display the preprint in It is made available under a CC-BY-NC-ND 4.0 International license.

taking any study tablets. The percentage $<60 \mathrm{nmol} / \mathrm{L}$ was $30.1 \%$, and just over one third $(35.6 \%)$ of people were predicted to have a concentration $<75 \mathrm{nmol} / \mathrm{L}$. Supplementary Table 5 shows a crossclassification of predictions from the three models.

The percentage of people with 'lower' predicted serum 25(OH)D concentration varied greatly with total intake of vitamin $\mathrm{D}$, ranging from $<2 \%$ amongst people whose total intake was $\geq 500 \mathrm{IU} /$ day to $>40 \%$ in those taking < $100 \mathrm{IU} /$ day (Table 4). Those with greater physical activity or more time outdoors were less likely to have low predicted $25(\mathrm{OH}) \mathrm{D}$ concentration. People with BMI $\geq 30 \mathrm{~kg} / \mathrm{m}^{2}$, or who lived alone, had poorer QoL, or smoked were more likely to be predicted to have lower deseasonalised serum $25(\mathrm{OH}) \mathrm{D}$ concentration than people who were not in these groups.

Table 4. Percentage of participants with predicted deseasonalised serum 25(OH)D concentration $<50$ $\mathrm{nmol} / \mathrm{L},<60 \mathrm{nmol} / \mathrm{L}$, and $<75 \mathrm{nmol} / \mathrm{L}$ prior to taking any study tablets by levels of predictor variables; predictions obtained by applying boosted regression tree models ${ }^{1}$ to baseline data for all participants of the D-Health Trial.

\begin{tabular}{|c|c|c|c|c|}
\hline \multirow[b]{2}{*}{ Predictor variable } & \multirow[b]{2}{*}{$\mathbf{N}(\%)^{2}$} & \multicolumn{3}{|c|}{ Predicted deseasonalised serum 25(OH)D concentration } \\
\hline & & $\%<50$ nmol & $\%<60$ nmoh & $\%<75 \mathrm{nmoh}$ \\
\hline \multicolumn{5}{|l|}{ Age (years) } \\
\hline$<70$ & $11086(52.0)$ & 25.1 & 28.7 & 27.5 \\
\hline 70 to $<75$ & $5796(27.2)$ & 23.0 & 29.8 & 40.8 \\
\hline$\geq 75$ & $4428(20.8)$ & 24.5 & 33.8 & 49.1 \\
\hline \multicolumn{5}{|l|}{ Sex } \\
\hline Men & $11530(54.1)$ & 21.8 & 27.1 & 37.8 \\
\hline Women & $9780(45.9)$ & 27.5 & 33.5 & 33.0 \\
\hline \multicolumn{5}{|l|}{ Month of randomisation } \\
\hline January & $814(3.8)$ & 20.4 & 22.1 & 37.6 \\
\hline February & $1582(7.4)$ & 19.3 & 20.0 & 27.3 \\
\hline March & $1517(7.1)$ & 23.9 & 29.1 & 33.1 \\
\hline April & $1433(6.7)$ & 25.6 & 33.3 & 34.0 \\
\hline May & $1419(6.7)$ & 36.1 & 46.5 & 41.6 \\
\hline June & $1298(6.1)$ & 50.6 & 61.9 & 61.6 \\
\hline July & $1596(7.5)$ & 46.4 & 58.0 & 58.1 \\
\hline August & $1675(7.9)$ & 25.6 & 35.8 & 32.9 \\
\hline September & $1948(9.1)$ & 22.9 & 30.5 & 31.7 \\
\hline October & 2557 (12.0) & 17.5 & 23.0 & 33.0 \\
\hline November & 2839 (13.3) & 13.2 & 14.9 & 26.8 \\
\hline December & 2632 (12.4) & 14.9 & 15.2 & 29.3 \\
\hline \multicolumn{5}{|c|}{ Ambient ultraviolet radiation $\left(\mathrm{J} / \mathrm{m}^{2}\right)^{3}$} \\
\hline$<1250$ & $3338(15.7)$ & 50.5 & 62.9 & 64.9 \\
\hline 1250 to $<2500$ & $4102(19.2)$ & 23.6 & 31.8 & 26.5 \\
\hline 2500 to $<3750$ & $3268(15.3)$ & 23.5 & 31.6 & 36.6 \\
\hline 3750 to $<5000$ & $3861(18.1)$ & 17.4 & 21.4 & 30.0 \\
\hline$\geq 5000$ & $6741(31.6)$ & 16.4 & 17.0 & 29.4 \\
\hline \multicolumn{5}{|l|}{ Physical activity (METs/week) } \\
\hline Low $(<18)$ & $6889(33.4)$ & 44.5 & 45.5 & 46.3 \\
\hline Moderate $(18$ to $<45)$ & $6835(33.1)$ & 14.7 & 27.2 & 33.6 \\
\hline High $(\geq 45)$ & $6902(33.5)$ & 11.7 & 15.3 & 24.9 \\
\hline
\end{tabular}


medRxiv preprint doi: https://doi.org/10.1101/2020.08.23.20180422; this version posted August 25, 2020. The copyright holder for this preprint (which was not certified by peer review) is the author/funder, who has granted medRxiv a license to display the preprint in

It is made available under a CC-BY-NC-ND 4.0 International license.

\begin{tabular}{|c|c|c|c|c|}
\hline \multirow[b]{2}{*}{ Predictor variable } & \multirow[b]{2}{*}{$\mathbf{N}(\%)^{2}$} & \multicolumn{3}{|c|}{ Predicted deseasonalised serum 25(OH)D concentration } \\
\hline & & $\%<50 \mathrm{nmoh}$ & $\%<60 \mathrm{nmoh}$ & $\%<75 \mathrm{nmoh}$ \\
\hline \multicolumn{5}{|l|}{ Time outdoors (hours/week) } \\
\hline$<5$ & $4066(19.6)$ & 58.6 & 51.0 & 46.5 \\
\hline 5 to $<10$ & $4240(20.4)$ & 25.2 & 39.8 & 44.7 \\
\hline 10 to $<15$ & $3763(18.1)$ & 15.8 & 34.9 & 42.1 \\
\hline 15 to $<25$ & $4548(21.9)$ & 11.9 & 13.5 & 23.6 \\
\hline$\geq 25$ & $4157(20.0)$ & 8.9 & 10.2 & 19.7 \\
\hline \multicolumn{5}{|l|}{ Tan moderately or deeply } \\
\hline No & 6929 (32.9) & 35.6 & 42.5 & 50.6 \\
\hline Yes & $14155(67.1)$ & 18.8 & 23.9 & 28.3 \\
\hline \multicolumn{5}{|l|}{ Body mass index $\left(\mathrm{kg} / \mathrm{m}^{2}\right)$} \\
\hline$<25$ & $6417(30.3)$ & 22.5 & 23.7 & 20.3 \\
\hline 25 to $<30$ & $9029(42.6)$ & 19.6 & 25.6 & 37.8 \\
\hline$\geq 30$ & $5745(27.1)$ & 33.6 & 44.2 & 49.7 \\
\hline \multicolumn{5}{|c|}{ Alcohol consumption (drinks/week) } \\
\hline$<1.0$ & $5046(24.6)$ & 29.9 & 40.0 & 52.7 \\
\hline $1.0-2.0$ & $3252(15.9)$ & 24.0 & 32.3 & 37.0 \\
\hline $2.1-7.0$ & $5852(28.6)$ & 23.1 & 27.4 & 37.2 \\
\hline $7.1-14.0$ & $3754(18.3)$ & 18.0 & 20.2 & 19.5 \\
\hline$>14.0$ & $2580(12.6)$ & 21.6 & 22.7 & 20.2 \\
\hline \multicolumn{5}{|l|}{ Current smoker } \\
\hline No & $20229(95.8)$ & 21.9 & 27.9 & 34.8 \\
\hline Yes & $896(4.2)$ & 79.9 & 78.0 & 55.8 \\
\hline \multicolumn{5}{|l|}{ Living alone } \\
\hline No & $16960(80.0)$ & 22.4 & 26.6 & 34.8 \\
\hline Yes & $4233(20.0)$ & 31.8 & 43.5 & 38.6 \\
\hline \multicolumn{5}{|l|}{ Self-rated quality of life } \\
\hline Excellent & 4359 (20.9) & 13.6 & 20.0 & 30.4 \\
\hline Very good & $9601(46.1)$ & 22.2 & 25.9 & 32.6 \\
\hline Good, fair or poor & $6855(32.9)$ & 33.9 & 42.1 & 42.8 \\
\hline \multicolumn{5}{|l|}{ Total intake of vitamin D (IU/day) ${ }^{4}$} \\
\hline$<100$ & $3866(18.2)$ & 41.5 & 45.8 & 56.4 \\
\hline 100 to $<200$ & $8872(41.8)$ & 33.0 & 43.0 & 46.0 \\
\hline 200 to $<500$ & $5151(24.3)$ & 12.2 & 15.3 & 24.3 \\
\hline$\geq 500$ & $3321(15.7)$ & 0.2 & 0.0 & 1.3 \\
\hline
\end{tabular}

${ }^{1}$ The models were fitted to a training dataset containing $\mathrm{n}=1788$ blood samples. The models for $<50 \mathrm{nmol} / \mathrm{L},<60 \mathrm{nmol} / \mathrm{L}$, and $<75$ $\mathrm{nmol} / \mathrm{L}$ used tree complexities of 5,2 , and 5 , respectively, learning rates of $0.001,0.001$, and 0.005 , respectively, and bag fractions of 0.5 , 0.5 , and 0.7, respectively, and their cross-validated deviance was minimised using 3850, 3850, and 1000 trees, respectively. ${ }^{2}$ Missing data: physical activity, 684; time outdoors, 536; tanning ability, 226; body mass index, 119; alcohol consumption, 826; current smoker, 185; living alone, 117; self-rated quality of life, 495 ; total intake of vitamin D, $100 .{ }^{3}$ Month-specific average erythemal daily dose at time of randomisation. Ambient ultraviolet radiation was included as a continuous variables in boosted regression tree models. For simplicity, we have presented summary statistics within categories of ultraviolet radiation. ${ }^{4}$ Total intake from diet and supplements.

\section{DISCUSSION}

To enable future exploratory analyses stratified by baseline vitamin D status, we developed BRT models to predict whether or not each participant in the D-Health Trial had 'low' deseasonalised serum $25(\mathrm{OH}) \mathrm{D}$ concentration prior to taking any study tablets. Separate models were fitted to predict concentrations $<50 \mathrm{nmol} / \mathrm{L},<60 \mathrm{nmol} / \mathrm{L}$, and $<75 \mathrm{nmol} / \mathrm{L}$, and all identified ambient UV radiation and total intake of vitamin D from food and supplements as the strongest predictors of a 'low' serum $25(\mathrm{OH}) \mathrm{D}$ concentration. The discriminatory ability of the models for $<50 \mathrm{nmol} / \mathrm{L}$ and $<60 \mathrm{nmol} / \mathrm{L}$ were very similar; it was slightly lower for the model for $<75 \mathrm{nmol} / \mathrm{L}$. Approximately one quarter of 
medRxiv preprint doi: https://doi.org/10.1101/2020.08.23.20180422; this version posted August 25, 2020. The copyright holder for this preprint (which was not certified by peer review) is the author/funder, who has granted medRxiv a license to display the preprint in

It is made available under a CC-BY-NC-ND 4.0 International license.

participants had predicted deseasonalised serum 25(OH)D concentration $<50 \mathrm{nmol} / \mathrm{L}(24.4 \%)$, and the percentages of participants who had predicted concentrations $<60 \mathrm{nmol} / \mathrm{L}$ and $<75 \mathrm{nmol} / \mathrm{L}$ were $30.1 \%$ and $35.6 \%$, respectively.

In the 2011-2013 Australian Health Survey (AHS) 15\% of people aged 65 to 74 years, and $20 \%$ of people aged $\geq 75$ years had serum $25(\mathrm{OH}) \mathrm{D}$ concentration $<50 \mathrm{nmol} / \mathrm{L} .{ }^{24}$ These values are somewhat higher than the $13 \%$ (non-deseasonalised) we observed in blood samples from people randomised to placebo. Similarly, $48 \%$ of our samples had serum $25(\mathrm{OH}) \mathrm{D}$ concentration $<75 \mathrm{nmol} / \mathrm{L}$ compared with the $60 \%$ reported for older people (aged $\geq 55$ years) in a recent analysis of determinants of vitamin D deficiency in the general Australian population using the AHS data. ${ }^{25}$ The AHS used a nationally representative sample and its estimates are survey-weighted to the Australian population (excluding people who live in very remote areas). ${ }^{26}$ The percentages we present are unweighted, so discordant estimates might reflect differences in residential location or ethnicity (91\% of our participants described their ancestry as British/European). ${ }^{4}$ Moreover, people participating in the DHealth Trial are, on average, healthier than the general older Australian population. ${ }^{4}$

The primary source of vitamin D is sun exposure. Hence, it is not surprising that ambient UV radiation should be an important predictor in our models. The strong contribution of total intake of vitamin $\mathrm{D}$ to the model is also consistent with expectations. Obesity and low levels of physical activity have been shown to be independent predictors of vitamin D deficiency in the general Australian population, ${ }^{25}$ and predictions from our model are consistent with these findings. Similarly, the association we observed between smoking and lower predicted serum $25(\mathrm{OH}) \mathrm{D}$ concentration was also noted in the AHS. ${ }^{24}$ Genetics account for considerable variability in serum 25(OH)D concentrations, ${ }^{27}$ and this is likely to explain some of the variation not accounted for by our models.

The percentage of participants with predicted deseasonalised concentration $<50 \mathrm{nmol} / \mathrm{L}$ was considerably higher than the observed percentage for all blood samples (24.4\% versus $10.7 \%)$ and this discrepancy might be explained, in part, by differences in supplemental intake of vitamin $\mathrm{D}$ at baseline and at the times when we collected blood samples. To be eligible to participate, people needed to be taking $\leq 500 \mathrm{IU} /$ day supplementary vitamin $\mathrm{D}$; after randomisation (when blood samples were collected) people could take $\leq 2000 \mathrm{IU} /$ day off-trial supplementary vitamin D without having to withdraw. However, we discouraged the use of high-dose supplementation, and the percentage consuming $\geq 500 \mathrm{IU} /$ day from food and supplements was not greatly higher in the training dataset (i.e. at time of blood draw) to at baseline (18.8\% versus $15.7 \%)$.

The model predicting $25(\mathrm{OH}) \mathrm{D}$ concentration $<50 \mathrm{nmol} / \mathrm{L}$ had an excellent NPV and poor PPV, both of which are partly explained by the low prevalence of samples with concentration $<50 \mathrm{nmol} / \mathrm{L}$. The low PPV will account for some of the discrepancy between the observed and predicted percentages. This has implications for analyses we perform stratified by this variable since there will be a considerable number of people classified incorrectly as having deseasonalised serum $25(\mathrm{OH}) \mathrm{D}$ concentration $<50 \mathrm{nmol} / \mathrm{L}$ which will reduce the probability that we will detect an actual effect (benefit or otherwise) of vitamin D supplementation amongst people with lower serum 25(OH)D. Conversely, if an interaction between randomisation and baseline serum $25(\mathrm{OH}) \mathrm{D}$ concentration is significant in future analyses, we can be reasonably confident that the actual effect is greater than estimated.

The poor PPV of the model for $<50 \mathrm{nmol} / \mathrm{L}$ highlights that predicting low concentrations is intrinsically difficult. Since the model for $<60 \mathrm{nmol} / \mathrm{L}$ had similar discriminatory power as the model for $<50 \mathrm{nmol} / \mathrm{L}$, we may perform exploratory analyses of D-Health outcomes stratified using a cutpoint of $60 \mathrm{nmol} / \mathrm{L}$. In contrast, the predictions from the model for $<75 \mathrm{nmol} / \mathrm{L}$ are not sufficiently precise to use for future analyses.

There are trade-offs inherent in predicting rather than measuring baseline vitamin $\mathrm{D}$ status. Any future analyses that are stratified by predicted deseasonalised serum $25(\mathrm{OH}) \mathrm{D}$ concentration must be considered exploratory. Some misclassification of true baseline vitamin D status is inevitable. We have relied heavily on self-reported data. Although we cleaned data during the course of the intervention, often phoning participants to check questionable survey responses, errors are likely to remain. Some data were not collected at the time blood was provided and we assumed that the rankings of time outdoors and physical activity were relatively stable during the year after 
medRxiv preprint doi: https://doi.org/10.1101/2020.08.23.20180422; this version posted August 25, 2020. The copyright holder for this preprint (which was not certified by peer review) is the author/funder, who has granted medRxiv a license to display the preprint in

It is made available under a CC-BY-NC-ND 4.0 International license .

randomisation. Likewise, we assumed stability of dietary habits. The UV radiation data are not ground-level measurements and, for blood samples collected from 2018 onwards, we used data from 2017. However, the relative ranking of areas is unlikely to have changed substantively, particularly since we used monthly average values. Further, since the machine learning algorithm implicitly handles any non-linear but one-to-one transformation from nominal to true values, the use of older data should not have had a deleterious effect on our modelling.

The merits of using BRT models have been enumerated elsewhere. ${ }^{14}$ We used this approach because: we could use all serum 25(OH)D concentrations regardless of whether some of the predictor variables had missing values with no need for imputation; we did not have to specify interactions; and we could introduce stochasticity through the use of a bag fraction. The latter is likely to improve the performance of the prediction model when applied to the entire cohort. Unlike a traditional single tree model, the BRT model is also less prone to over-fitting the training data.

Motivated by the prohibitive cost of collecting blood samples from all participants in a large field trial of more than 20,000 participants, we have exploited compliance monitoring data to develop models to predict serum $25(\mathrm{OH}) \mathrm{D}$ concentration. These models are intended to generate predictions for the DHealth Trial so that we may perform exploratory analyses stratified by the predicted baseline vitamin D status. However, the general approach we have outlined may also prove useful in other trial settings where there is an obstacle to exhaustive data collection.

Clinical Trial Registration Number: Australian New Zealand Clinical Trials Registry: ACTRN12613000743763. Registered on 4 July 2013.

\section{Disclosures}

The authors have nothing to disclose.

\section{Acknowledgements}

We would like to acknowledge the D-Health Trial staff and members of the Data and Safety Monitoring Board (Patricia Valery, Ie-Wen Sim, Kerrie Sanders). We also extend our thanks to the DHealth Trial participants who committed to this research.

\section{Grants and fellowships}

The D-Health Trial is funded by National Health and Medical Research Council (NHMRC) project grants (APP1046681, APP1120682). PM Webb and DC Whiteman are supported by fellowships from the NHMRC (GNT1173346, APP1155413). DSA McLeod is supported by a Metro North Clinician Research Fellowship and a Queensland Advancing Clinical Research Fellowship. H Pham is supported by a University of Queensland PhD Scholarship. MW Clarke is affiliated to Metabolomics Australia, University of Western Australia, Perth, Western Australia, Australia. Measurement of serum 25(OH)D concentration was supported by infrastructure funding from the Western Australian State Government in partnership with the Australian Federal Government, through Bioplatforms Australia and the National Collaborative Research Infrastructure Strategy (NCRIS).

\section{CRediT author statement}

Mary Waterhouse: Conceptualisation, Methodology, Formal analysis, Data Curation, Writing Original Draft, Writing - Review \& Editing, Visualisation. Catherine Baxter: Investigation, Data Curation, Project administration. Briony Duarte Romero: Investigation, Data Curation, Project administration. Donald S. A. McLeod: Writing - Review \& Editing. Dallas R. English: Conceptualisation, Funding acquisition. Bruce K. Armstrong: Conceptualisation, Writing - Review \& Editing, Funding acquisition. Michael W. Clarke: Resources, Writing - Review \& Editing. Peter R. Ebeling: Conceptualisation, Writing - Review \& Editing, Funding acquisition. Gunter Hartel: Writing - Review \& Editing. Michael G. Kimlin: Conceptualisation, Writing - Review \& Editing, Funding acquisition. Rachel L. O'Connell: Conceptualisation, Writing - Review \& Editing, Funding acquisition. Hai Pham: Data Curation. Rachael M. Rodney Harris: Resources, Writing - Review \& 
medRxiv preprint doi: https://doi.org/10.1101/2020.08.23.20180422; this version posted August 25, 2020. The copyright holder for this preprint (which was not certified by peer review) is the author/funder, who has granted medRxiv a license to display the preprint in It is made available under a CC-BY-NC-ND 4.0 International license .

Editing. Jolieke C. van der Pols: Conceptualisation, Writing - Review \& Editing, Funding acquisition. Alison J. Venn: Conceptualisation, Writing - Review \& Editing, Funding acquisition. Penelope M. Webb: Conceptualisation, Writing - Review \& Editing. David C. Whiteman: Conceptualisation, Writing - Review \& Editing. Rachel E. Neale: Conceptualisation, Methodology, Investigation, Data Curation, Writing - Review \& Editing, Supervision, Project administration, Funding acquisition. 
medRxiv preprint doi: https://doi.org/10.1101/2020.08.23.20180422; this version posted August 25, 2020. The copyright holder for this preprint (which was not certified by peer review) is the author/funder, who has granted medRxiv a license to display the preprint in

It is made available under a CC-BY-NC-ND 4.0 International license .

\section{REFERENCES}

1. Autier P, Boniol M, Pizot C, Mullie P. Vitamin D status and ill health: a systematic review. The Lancet Diabetes \& endocrinology 2014; 2(1): 76-89.

2. Autier P, Mullie P, Macacu A, Dragomir M, Boniol M, Coppens K, Pizot C, Boniol M. Effect of vitamin $D$ supplementation on non-skeletal disorders: a systematic review of meta-analyses and randomised trials. The Lancet Diabetes \& endocrinology 2017; 5(12): 986-1004.

3. Manson JE, Cook NR, Lee IM, Christen W, Bassuk SS, Mora S, Gibson H, Gordon D, Copeland T, D'Agostino D, Friedenberg G, Ridge C, Bubes V, Giovannucci EL, Willett WC, Buring JE. Vitamin D Supplements and Prevention of Cancer and Cardiovascular Disease. The New England journal of medicine 2019; 380(1): 33-44.

4. Neale RE, Armstrong BK, Baxter C, Duarte Romero B, Ebeling P, English DR, Kimlin MG, McLeod DS, RL OC, van der Pols JC, Venn AJ, Webb PM, Whiteman DC, Wockner L. The DHealth Trial: A randomized trial of vitamin $D$ for prevention of mortality and cancer. Contemporary clinical trials 2016; 48: 83-90.

5. Scragg R. Emerging Evidence of Thresholds for Beneficial Effects from Vitamin D Supplementation. Nutrients 2018; 10(5).

6. Waterhouse M, English DR, Armstrong BK, Baxter C, Duarte Romero B, Ebeling PR, Hartel G, Kimlin MG, McLeod DSA, O'Connell RL, van der Pols JC, Venn AJ, Webb PM, Whiteman DC, Neale RE. A randomized placebo-controlled trial of vitamin $D$ supplementation for reduction of mortality and cancer: Statistical analysis plan for the D-Health Trial. Contemporary clinical trials communications 2019; 14: 100333.

7. Tran B, Armstrong BK, McGeechan K, Ebeling PR, English DR, Kimlin MG, Lucas R, van der Pols JC, Venn A, Gebski V, Whiteman DC, Webb PM, Neale RE. Predicting vitamin D deficiency in older Australian adults. Clinical endocrinology 2013; 79(5): 631-40.

8. NASA Goddard Earth Sciences Data Information Services Center (GES DISC). DAAC OMI data products and data access. NASA website. http://acdisc.gesdisc.eosdis.nasa.gov (accessed June 9 2020).

9. Clarke MW, Tuckey RC, Gorman S, Holt B, Hart PH. Optimized 25-hydroxyvitamin D analysis using liquid-liquid extraction with $2 \mathrm{D}$ separation with $\mathrm{LC} / \mathrm{MS} / \mathrm{MS}$ detection, provides superior precision compared to conventional assays. Metabolomics 2013; 9(5): 1031-40.

10. CDC Vitamin D Standardization-Certification Program (CDC VDSCP). March 2020. https://www.cdc.gov/labstandards/pdf/hs/CDC Certified Vitamin D Procedures-508.pdf (accessed August 4 2020).

11. Institute of Medicine Committee to Review Dietary Reference Intakes for Vitamin D, Calcium. The National Academies Collection: Reports funded by National Institutes of Health. In: Ross AC, Taylor CL, Yaktine AL, Del Valle HB, eds. Dietary Reference Intakes for Calcium and Vitamin D. Washington (DC); 2011.

12. The Royal College of Pathologists of Australasia. Position Statement: Use and Interpretation of Vitamin D testing. May 2019. https://www.rcpa.edu.au/Library/College-Policies/PositionStatements/Use-and-Interpretation-of-Vitamin-D-Testing (accessed August 4 2020).

13. Holick MF, Binkley NC, Bischoff-Ferrari HA, Gordon CM, Hanley DA, Heaney RP, Murad MH, Weaver CM. Evaluation, treatment, and prevention of vitamin D deficiency: an Endocrine Society clinical practice guideline. The Journal of clinical endocrinology and metabolism 2011; 96(7): 1911-30.

14. Elith J, Leathwick JR, Hastie T. A working guide to boosted regression trees. Journal of Animal Ecology 2008; 77(4): 802-13.

15. Friedman JH. Greedy function approximation: A gradient boosting machine. The Annals of Statistics 2001; 29(5): 1189-232.

16. Hastie T, Friedman JH, Tibshirani R. The elements of statistical learning : data mining, inference, and prediction: New York : Springer; 2001.

17. Agresti A, Coull BA. Approximate is better than "exact" for interval estimation of binomial proportions. The American Statistician 1998; 52: 119-12. 
medRxiv preprint doi: https://doi.org/10.1101/2020.08.23.20180422; this version posted August 25, 2020. The copyright holder for this preprint (which was not certified by peer review) is the author/funder, who has granted medRxiv a license to display the preprint in It is made available under a CC-BY-NC-ND 4.0 International license.

18. R Core Team. R: A language and environment for statistical computing Vienna, Austria $\mathrm{R}$ Foundation for Statistical Computing; 2019

19. Brandon Greenwell BB, Jay Cunningham and GBM Developers. gbm: Generalized Boosted Regression Models. 2.1.5 ed; 2019.

20. Sing T, Sander O, Beerenwinkel N, Lengauer T. ROCR: visualizing classifier performance in R. Bioinformatics (Oxford, England) 2005; 21(20): 3940-1.

21. Robin X, Turck N, Hainard A, Tiberti N, Lisacek F, Sanchez JC, Müller M. pROC: an opensource package for $\mathrm{R}$ and $\mathrm{S}+$ to analyze and compare ROC curves. BMC bioinformatics 2011; 12: 77.

22. Márcia Barbosa A, Real R, Muñoz A-R, Brown JA. New measures for assessing model equilibrium and prediction mismatch in species distribution models. 2013; 19(10): 1333-8.

23. López-Ratón M, Rodríguez-Álvarez MX, Cadarso-Suárez C, Gude-Sampedro F. OptimalCutpoints: An R Package for Selecting Optimal Cutpoints in Diagnostic Tests. 2014 2014; 61(8): 36 \%J Journal of Statistical Software.

24. Australian Bureau of Statistics. Australian Health Survey: biomedical results for nutrients, 2011-12. 2014.

http://www.abs.gov.au/ausstats/abs@.nsf/Lookup/4364.0.55.006main+features12011-12 (accessed 23 June 2020).

25. Malacova E, Cheang PR, Dunlop E, Sherriff JL, Lucas RM, Daly RM, Nowson CA, Black LJ. Prevalence and predictors of vitamin $D$ deficiency in a nationally representative sample of adults participating in the 2011-2013 Australian Health Survey. The British journal of nutrition 2019; 121(8): 894-904.

26. Australian Bureau of Statistics. Australian Health Survey: users' guide, 2011-2013. . 2013. http://www.abs.gov.au/ausstats/abs@.nsf/mf/4363.0.55.001 (accessed 26 June 2020).

27. Manousaki D, Mitchell R, Dudding T, Haworth S, Harroud A, Forgetta V, Shah RL, Luan J, Langenberg C, Timpson NJ, Richards JB. Genome-wide Association Study for Vitamin D Levels Reveals 69 Independent Loci. American journal of human genetics 2020; 106(3): 327-37. 